\title{
The Role of Sexual Self-Control as Moderator between Sexual Desire and Premarital Sexual Behaviors
}

\author{
Chindy Kencana Sari ${ }^{1}$, Marselius Sampe Tondok ${ }^{2}$, Darmawan Muttaqin ${ }^{3}$ \\ 1,2,3Faculty of Psychology, University of Surabaya
}

Submitted 21 November 2018 Accepted 18 November 2019 Published 20 April 2020

\begin{abstract}
Sexual desire can be one of the antecedents for individual premarital sexual behavior. Otherwise, sexual self-control can prevent individuals from engaging premarital sexual behavior. This study aimed to examine the role of self-control in moderating the relationship between sexual desire and premarital sexual behavior. This study involved 209 emerging adults (18-25 years old) who were dating and not undergoing a long-distance relationship. The current study used Premarital Sexual Permissiveness measurement, dyadic sexual desire subscale from Sexual Desire Inventory-II, general sex-drive and stimulus-elicited sex-drive subscales from Perceived Sexual Control to measure premarital sexual behavior, sexual desire, and sexual selfcontrol respectively. Results of regression analysis showed that sexual self-control did not moderate the relationship between sexual desire and kissing $\left(\Delta \mathrm{R}^{2}=0.006, \mathrm{p}>0.05\right)$, as well as sexual desire and petting $\left(\Delta \mathrm{R}^{2}=0.001, \mathrm{p}>0.05\right)$. However, self-control could be a moderator in the relationship between sexual desire and intercourse $\left(\Delta R^{2}=0.027, p<0.01\right)$.
\end{abstract}

Keywords: premarital sexual behavior; sexual desire; sexual self-control

Premarital sexual behavior is often done as the manifestation of love toward partner during the course of dating relationship. Dating is a form of exploration in relationship with others, particularly intimate relationship with a partner during period leading to adulthood (Arnett, 2005; Baron, Byrne, \& Watson, 2001). In dating relationship, there are various intimacy needs that should be fulfilled including sexual intimacy (Arnett, 2004). Thus, physical touch and even intercourse become the needs of couple in a relationship. In Indonesia, premarital sexual behavior is increasingly frequent and no longer considered a taboo (Rahardjo et al., 2017; Rany, 2012).

\footnotetext{
${ }^{1}$ Address for corespondence:

darmawan.muttaqin@staff.ubaya.ac.id
}

Reiss (1964) first proposed various forms of sexual behavior i.e., kissing, petting, and intercourse. Kissing is a contact between lips that occurs with touches in other body parts; petting includes caressing sex organ, oral sex, and pinning one's genital to partner's before orgasm; and intercourse which is the activity of inserting penis into vagina followed by ejaculation until reaching the orgasm stage (VandenBos, 2006).

Previous studies found individual motivations in doing sexual behavior including love, curiosity, and couple's similar attitude towards sexual behavior (Pinter \& Tomori, 2000; Yoon, 2004). Specifically, Smiller (2008) found that man engages in sexual behavior based on several reasons i.e., love for partner, 
thinking that dating partner also wants to have sex, curiosity about the act of sex, and the presence of sexual desire. In addition, previous studies also found that family and friend factors can be the predictors of sexual behavior (Savioja, Helminen, Fröjd, Marttunen, \& KaltialaHeino, 2018; Yan et al., 2010).

In Indonesia, some researchers had attempted to discover the antecedents of sexual behavior. A study by Suwarsi (2016) found that individual who has accessed pornographic content will be excited, addicted, and developing desire to practice it in everyday life. Another finding showed that individual who is tolerant towards pornographic content is more likely to engage in premarital sexual behavior (Mardyantari et al., 2018). It can be concluded that exposure to pornographic content can be one of the driving factors for someone to do premarital sexual behavior.

Past studies about premarital sexual behavior did not only focus on antecedent factors causing the behavior but also factors that prevent individual from engaging it. Sexual self-control model was used to determine psychological factors that influence individual to avoid premarital sexual behavior (Kennett, Humphreys, \& Patchell, 2009; Quinn-Nilas, Kennett, \& Humphreys, 2013). Studies on sexual selfcontrol had found that traditional gender norms and stigmas attached to virginity are strongly affecting individual to avoid premarital sexual behavior (Kennett, Humphreys, \& Bramley, 2013; QuinnNilas \& Kennett, 2018). As an effort to confirm the influence of sexual self-control in avoidance of premarital sexual behavior, the present study attempted to examine the role of sexual self-control as moderator between sexual desire and premarital sexual behavior. Premarital sexual behavior will not occur if individual does not have sexual desire. Sexual desire is person's urge to perform sexual behavior which arises due to external stimuli or sexual thoughts represented in the memory (Beck, Bozman, \& Qualtrough, 1991; Holloway \& Wylie, 2015; Kavanagh, Andrade, \& May, 2005; Toates, 2009). Sarwono (2013) also stated that premarital sexual behavior happens due to sexual desire. Furthermore, Levine (2003) explained specifically that sexual desire is formed by interaction in neuroendocrine system which provokes urges, cognitive process causing desire, and motivation that can cause someone to want to perform sexual behavior.

If sexual desire can spur an individual to do premarital sexual behavior, reversely, sexual self-control is able to become a buffer from the conduct. This is because sexual self-control is an ability to control one's sexual behavior so that it can be avoided (Baumeister, Vohs, \& Tice, 2007; Bouffard \& Miller, 2014; Bryan, Schindeldecker, \& Aiken, 2001). Individual who is able to direct their behavior towards positive consequences tend to avoid deviant behaviors such as premarital sex (Aviyah \& Farid, 2014) and be able to regulate emotions to control their urges (Ugoji, 2014). On the other hand, someone with lower self-control will be oriented towards self-satisfaction including engaging in premarital sexual behavior (Angelina \& Matulessy, 2013).

Premarital sexual behavior may occur due to sexual desire and reversely sexual self-control is able to repress sexual desire so that the behavior can be avoided. Thus, the hypothesis proposed was sexual selfcontrol had a role in moderating relationship between sexual desire and premarital sexual behavior. 


\section{Methods}

\section{Participants and instruments}

Participants were chosen by considering the criteria of being in heterosexual relationships for at least 3 months and lived in the same city with partners.

Premarital Sexual Permissiveness (PSP; Reiss, 1964) was used to measure premarital sexual behavior. PSP contained nine items which measures three types of premarital sexual behavior i.e., kissing (three items e.g., "My partner and I kiss in a quiet place"), petting (six items e.g., "On a date, my partner and I like to touch each other's body"), and intercourse (three items e.g., "We engage in intercourse in a quiet place"). PSP used five responses ranging from 1 (never) to 5 (always). PSP scale tryout involving 56 participants showed coefficient reliability of 0.557 for kissing, 0.794 for petting, and 0.723 for intercourse. Meanwhile the present study had coefficient reliability of 0.732 for kissing, 0.870 for petting, and 0.739 for intercourse.

\section{Sexual desire}

The 8-item Dyadic Sexual Desire subscale from Sexual Desire Inventory-II (SDI-II; Spector, Carey, \& Steinberg, 1996) was used to measure sexual desire. The response choice consisted of five choices from 1 (no urge, no desire, not important) to 5 (strong urge, strong desire, very important) with items such as "How important for you to fulfill sexual desire through intercourse with your partner?". Sexual desire scale had coefficient reliability of 0.759 from tryout involving 56 participants whilst in the present study had coefficient reliability of 0.901 .

\section{Sexual self-control}

General sex-drive and stimulus-elicited sex-drive subscales from Perceived Sexual Control (PSC; Exner, Meyer-Bahlburg, \& Ehrhardt, 1992) were used to measure sexual self-control. There were 13 items used which consisted of 6-item general sex-drive subscale (e.g., "Sexual urges control my life") and 7-item stimuluselicited sex-drive (e.g., "I cannot resist when I get an opportunity to have sex"). Responses towards sexual self-control scale varied from 1 (strongly disagree) to 5 (strongly agree). Tryout involving 56 participants showed that the scale had reliability coefficient of 0.219 , therefore researchers dropped 7 items and the reliability coefficient went up to 0.781 . The remaining items were 3 items in general sex-drive subscale and 3 items in stimuluselicited sex-drive. In this study, sexual selfcontrol scale had reliability coefficient of 0.906 .

\section{Data analysis procedure}

Hypothesis testing employed moderator variable analysis according to Baron and Kenny's approach (Baron \& Kenny, 1986) with the help of IBM SPSS 21.0 program. Prior to the analysis, moderator was established by multiplying sexual desire and sexual self-control variables. Multiple regression analysis was used to examine the moderator (see Figure 1) i.e., 1) sexual desire model, 2) sexual desire and sexual self-control model, and 3) sexual desire, sexual self-control, and moderator (sexual desire $x$ sexual self-control) model. Additional analysis with ANOVA was performed to find out gender difference in sexual behavior, sexual desire, and sexual self-control. 


\section{Result}

Participants of this study were 209 people consisted of 83 males (39.7\%) and 126 females $(60.3 \%)$, with age ranged from 18 25 years old $(\mathrm{M}=21.50, \mathrm{SD}=1.707)$ and the average length of dating period 20.73 months $(\mathrm{SD}=16.709)$.

The prevalence of sexual behavior in the participants of this study was including $12.9 \%$ participants who had never engaged in premarital sexual behavior either kissing, petting, nor intercourse. The majority of participants had done premarital sexual behavior i.e., kissing partners (86.6\%), caressing partners' body e.g., breast and/or genital $(66.5 \%)$, doing oral sex $(55.0 \%)$, pressing at each other's genital (54.1\%), and doing intercourse with partners (41.1\%).

Results of regression analysis (Table 1.) showed that sexual self-control was unable to moderate relationship between sexual desire and kissing and petting.
However, sexual self-control could become a predictor in the decrease of petting $(\beta=$ $0.267, \mathrm{p}<0.001)$. In addition, sexual selfcontrol could moderate relationship between sexual desire and intercourse with effective contribution of $2.7 \%$. The prevalence of intercourse could be predicted by sexual desire $(\beta=0.673, \mathrm{p}<$ 0.001 ) but interaction between sexual desire and sexual self-control could prevent intercourse $(\beta=-0.253, p<0.01)$.

The role of sexual self-control in moderating relationship between sexual desire and intercourse is illustrated in Figure 2. If an individual had low sexual self-control, the possibility for intercourse to happen became higher. On the other hand, if an individual had high sexual selfcontrol then the possibility of performing intercourse became lower even with an increase of sexual desire. It could be concluded that sexual self-control is able to be a buffer for the effect of sexual desire towards intercourse.

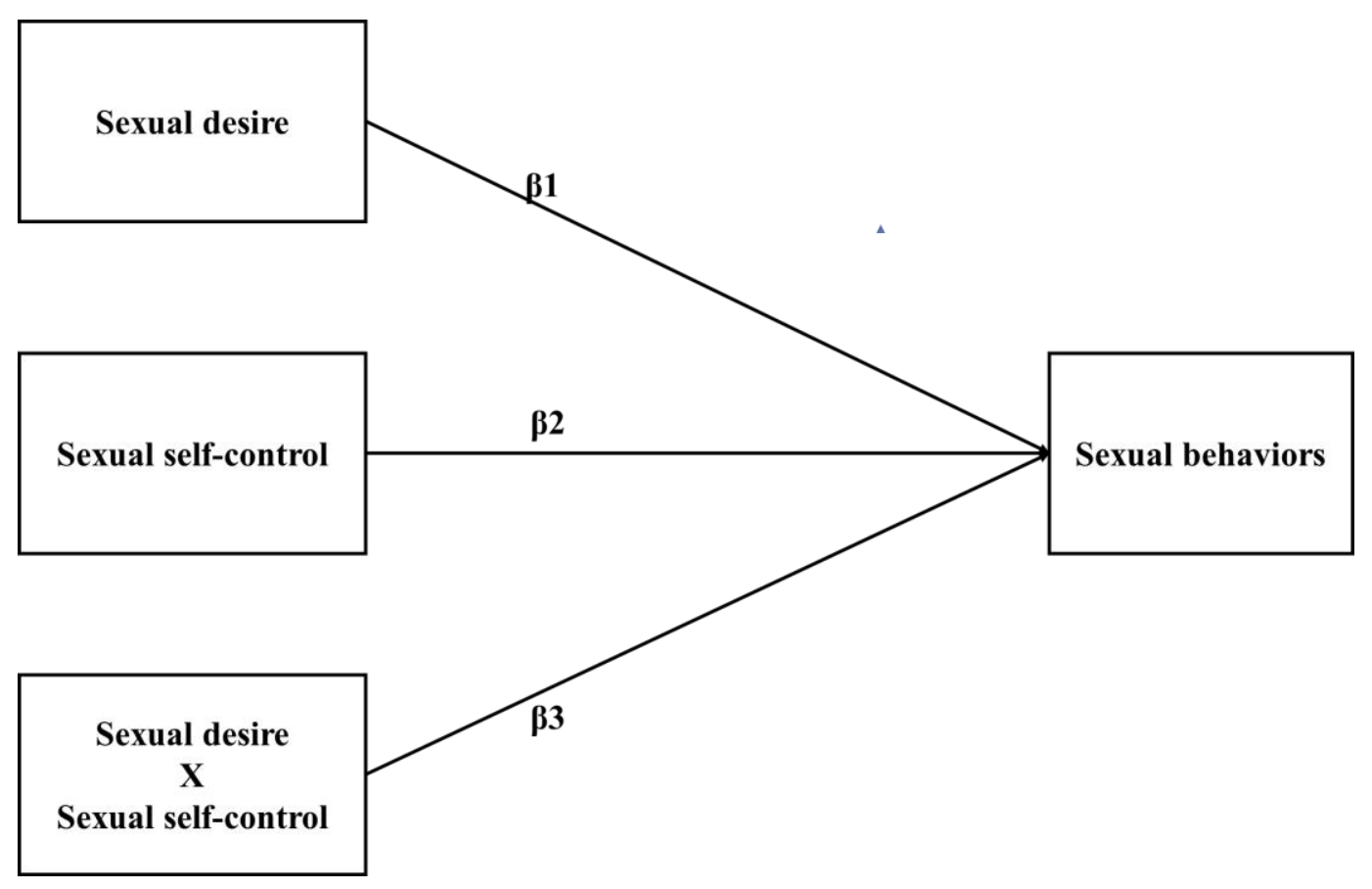

Figure 1. Regression analysis of study model 
Results of ANOVA showed score difference in petting $(\mathrm{F}=11.558, \mathrm{p}<0.01)$, intercourse $(\mathrm{F}=5.312, \mathrm{p}<0.05)$, sexual desire $(\mathrm{F}=41.476, \mathrm{p}<0.001)$ and sexual self-control $(\mathrm{F}=23.968, \mathrm{p}<0.001)$ between gender (Table 2). However, there was no gender difference in kissing $(\mathrm{F}=0.189, \mathrm{p}>$ 0.05). Based on descriptive analysis, petting, intercourse, and sexual desire in men tend to be higher while sexual selfcontrol tend to be higher in women.

Table 1.

Regression Variables towards Sexual Behaviors

\begin{tabular}{|c|c|c|c|c|c|c|c|}
\hline & \multirow{2}{*}{ Model } & \multicolumn{2}{|c|}{ Kissing } & \multicolumn{2}{|c|}{ Petting } & \multicolumn{2}{|c|}{ Intercourse } \\
\hline & & $\Delta \mathbf{R}^{2}$ & $\beta$ & $\Delta \mathbf{R}^{2}$ & $\beta$ & $\Delta \mathbf{R}^{2}$ & $\beta$ \\
\hline 1 & SD & $0.207^{* * *}$ & $0.455^{* * *}$ & $0.552^{* * *}$ & $0.743^{* * *}$ & $0.351^{* * *}$ & $0.593^{* * *}$ \\
\hline \multirow{3}{*}{2} & SD & \multirow{2}{*}{0.001} & $0.479^{* * *}$ & \multirow{2}{*}{$0.026^{* * *}$} & $0.532^{* * *}$ & \multirow{2}{*}{$0.030^{* *}$} & $0.367^{* * *}$ \\
\hline & SSC & & 0.031 & & $-0.267^{* * *}$ & & $-0.285^{* *}$ \\
\hline & SD & & $0.620^{* * *}$ & & $0.583^{* * *}$ & & $0.673^{* * *}$ \\
\hline \multirow[t]{2}{*}{3} & SSC & 0.006 & 0.162 & 0.001 & $-0.219^{*}$ & $0.027^{* *}$ & 0.001 \\
\hline & $S D \times S S C$ & & -0.117 & & -0.042 & & $-0.253^{* *}$ \\
\hline
\end{tabular}

model 1 = sexual desire; model 2 = sexual desire, sexual self-control ; model 3 = sexual desire, sexual self-control, sexual desire $\mathrm{x}$ sexual self-control; $\mathrm{SD}=$ sexual desire ; $\mathrm{SSC}=$ sexual self-control ${ }^{*} \mathrm{p}<0.05,{ }^{* *} \mathrm{p}<0.01,{ }^{* * *} \mathrm{p}<0.001$

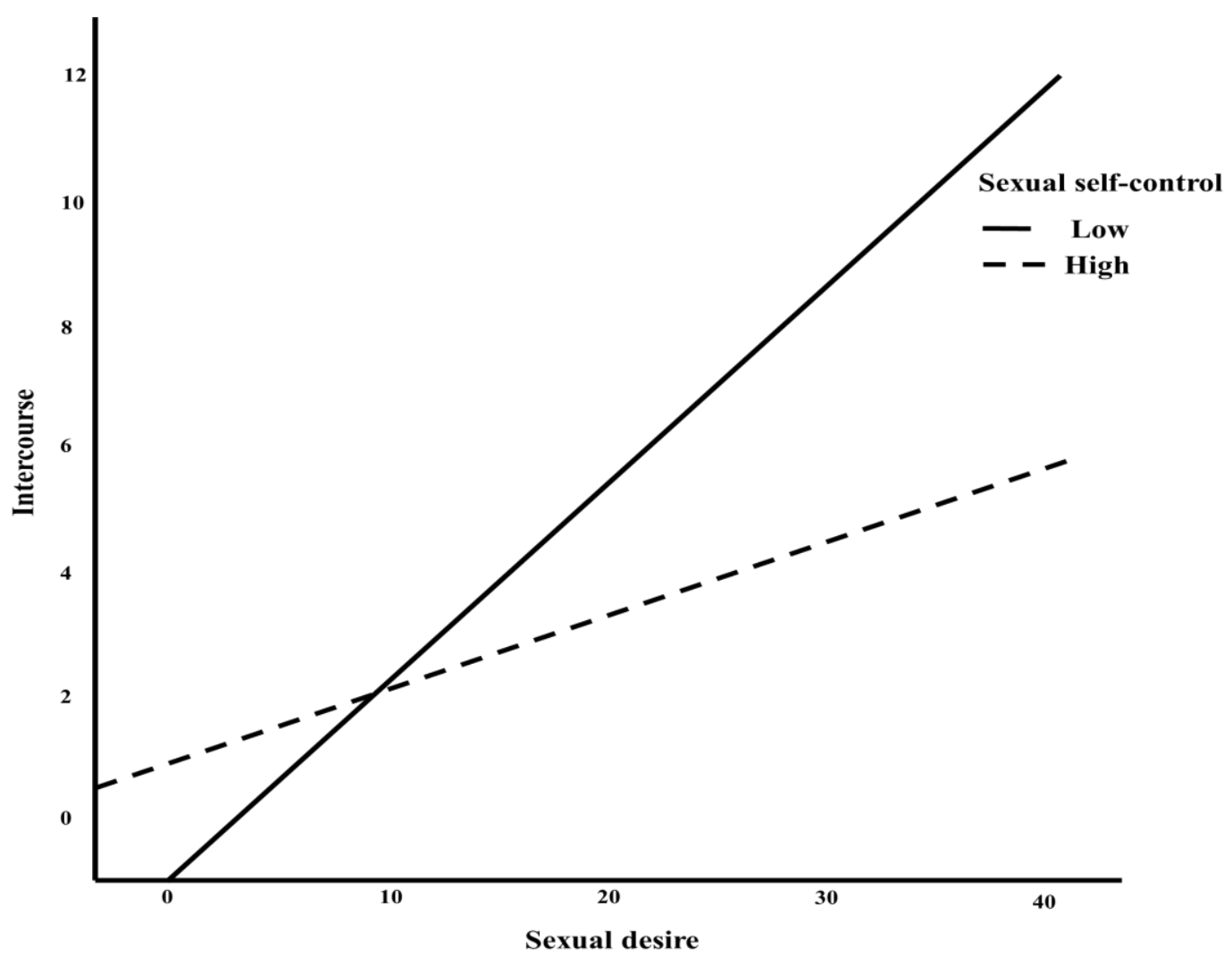

Figure 2. Relationship between sexual desire and intercourse with sexual self-control as moderator 
SARI, et al

Table 2.

Standard Deviation of Variable Scores According to Gender

\begin{tabular}{lrcc}
\hline \multirow{2}{*}{ Variable } & \multicolumn{2}{c}{ Male } & \multirow{2}{*}{ F } \\
\cline { 2 - 3 } & $7.51(3.14)$ & $7.32(3.12)$ & 0.189 \\
\cline { 2 - 3 } Kissing & $12.34(6.16)$ & $9.38(6.15)$ & $11.558^{* *}$ \\
Petting & $4.31(3.48)$ & $3.16(3.53)$ & $5.312^{*}$ \\
Intercourse & $18.33(7.10)$ & $11.69(7.41)$ & $41.476^{* * *}$ \\
Sexual desire & $11.45(6.26)$ & $15.94(6.62)$ & $23.968^{* * *}$ \\
Sexual self-control & &
\end{tabular}

\section{Discussion}

This study showed that majority of respondents who were entering adulthood had done premarital sexual behaviors, such as kissing, petting, and intercourse. This result was in line with previous studies that found an increase in premarital behavior when individuals entered the age of 18-20 years old or when individuals were studying in college (Vasilenko, Linden-Carmichael, Lanza, \& Patrick, 2018). First experience of premarital sexual behavior tends to be positive during emerging adulthood compared to adolescence (Vasilenko, Maas, \& Lefkowitz, 2015). This is because period leading to adulthood is an important phase to explore things related to romantic relationship and sexuality (Arnett, 2000) and also critical period to gain new experience about sex (Lefkowitz, 2005).

The results of this study found that sexual self-control could not moderate the relation between sexual desire and kissing and petting. However, sexual self-control can moderate the relation between sexual desire and intercourse. These results clarified previous study that found sexual self-control repressing sexual desire so that sexual behavior can be avoided in homosexual couples (Adam, Teva, \& de Wit,
2008). Previous study involved homosexual participants whereas the present study involved heterosexual participants and measured sexual behaviors specifically kissing, petting, and intercourse. This study had proven the importance of sexual self-control which can prevent individual from engaging in intercourse before marriage.

The absence of sexual self-control in moderating the relation between sexual desire with kissing and petting indicated that kissing and petting are not considered necessary to avoid in relationships. Kissing is considered as an expression of affection towards partner while petting is done to get pleasure. This was reflected in majority of participants who had kissed, caressed partner's body i.e. breast and/or genital, performed oral sex, and touched each other's genitals.

This finding showed the influence of globalization which is marked by the development of communication and information media (Nurhaidah \& Musa, 2015). Through communication and information media that are accessible with internet, people can access information without time and space constraints. It is not surprising if there is a shift in values, traits, and mindsets of a particular society (Nurhaidah \& Musa, 2015). For example, Indonesian people with Eastern culture, 
which emphasizes the values of obedience and purity, have begun to shift to Western culture which is characterized by freedom of expression, individualism, and secularism (Rahman, 2013). Therefore, kissing which was originally taboo begins to be considered as an expression of affection towards partner. This is inseparable from exposure to Western culture that displays kissing as a form of affection towards partner. In addition, information related to sexual behavior is more accessible via internet (Brown \& Cantor, 2000).

The role of sexual self-control in repressing sexual desire to avoid intercourse showed that intercourse is still considered as a behavior that violates morality. This is because moral principles are intended to regulate individual behavior and social life (Haidt, 2013). When intercourse before marriage is considered as forbidden (Sarwono, 2013), individual will try to exercise self-control to avoid intercourse before marriage. Avoiding intercourse, which is considered as moral behavior, will lead individual to gain social acceptance whereas doing intercourse before marriage is considered as moral violation thus will cause individual to receive rejection and punishment from their community (Sarwono, 2013).

Individual capability to control their premarital sexual behavior is related to norms, laws, and values that are believed by individual. For example, if individual believes that premarital sexual behavior is wrong, they will try to avoid it (Aalsma et al., 2013). In addition, religiosity can be a factor related to premarital sexual behavior. The high level of religiosity possessed by individual can be a predictor of low premarital sexual behavior (Aalsma et al., 2013; Vasilenko, Duntzee, Zheng, \& Lefkowitz, 2013). Individual who internalizes their religion teachings will consider prohibition by their religion and its negative consequences if engaging in prohibited behaviors, including premarital sexual behavior (Longest \& Vaisey, 2008; Rostosky, Regnerus, \& Wright, 2003; Vasilenko \& Espinosa-Hernández, 2019). Therefore, individual who has high level of religiosity tends to resist premarital sexual behavior (Brelsford, Luquis, \& Murray-Swank, 2011; Penhollow, Young, \& Denny, 2005) and also does not engage in premarital sexual behavior (Lefkowitz, Gillen, Shearer, \& Boone, 2004; Luquis, Brelsford, \& Pérez, 2015). Conversely, nonreligious individual tends to be more tolerant towards premarital sexual behavior (Willoughby \& Carroll, 2010).

Aside from sexual self-control and religiosity, social control can also suppress premarital sexual behavior. Social control becomes a set of rule to control deviant behavior in order to abide the rules in society (Janowitz, 1975). Vasilenko, et al. (2013) explained that individual can avoid sexual behavior by obeying society norms and internalizing norms related to premarital sexual behavior in daily life. Moreover, individual from collectivist culture i.e., Indonesian people, tend to value social norms more than personal goals. Thus, they are better trained at controlling self from conducting behavior that violates social norms (Pokhrel et al., 2018). If the society still adheres to rigid social norms related to premarital sexual behavior, individual will try to avoid it because the behavior violates moral norms in the society (Victor, Miles, \& Vaisey, 2015). In a community with strong belief that woman has to remain virgin until marriage, woman will try to abstain from premarital sexual behavior (Espinosa-Hernández, Vasilenko, \& Bámaca-Colbert, 2016). Thus, value and norm cultivation based on religion and society can function as social 
control for individual to regulate their sexual desire to evade premarital sexual behavior.

Gender differences in sexual behavior, sexual desire, and sexual self-control indicated that men engaging in sexual behavior based on transpiring sexual desire which is not balanced with sufficient sexual self-control. This finding is in accordance with previous studies which found the tendency of men to engage in sexual behavior because it happened by chance, based on emerging desires (Pinter \& Tomori, 2000; Smiler, 2008). The role of dating mood in the form of romantic atmosphere felt together with partner could be a driving factor for the emerging of unplanned sexual behavior (Yoon, 2004).

Sexual desire in man appears more frequent and intense than woman. It is manifested in form of sexual fantasies i.e., sexual relations desired, number of partners expected, or ways to satisfy sexual desire (Baumeister, Catanese, \& Vohs, 2001). In addition, premarital sexual behavior is more acceptable and considered as embodiment of masculinity for man (Smith, Guthrie, \& Oakley, 2005). It is not surprising if man experiences more positive feelings when he first engages in premarital sexual behavior in emerging adulthood (Vasilenko et al., 2015).

In contrast to man, woman has better sexual self-control therefore woman needs to deliberate before engaging in premarital sexual behavior. For example, woman considers the possibility of pregnancy and regret caused by premarital sexual behavior (Lefkowitz, Vasilenko, \& Leavitt, 2016). Woman also worries if her premarital sexual behavior is found out by parents, family name would be tarnished (Vasilenko, Espinosa-Hernández, \& Halgunseth, 2016). Not only deliberation and concerns over premarital sexual behavior, woman still believes that virginity is a valuable gift for her best partner (Carpenter, 2002). Thus, woman engages in sexual behavior because of love for her partner (Pinter \& Tomori, 2000; Yoon, 2004) and commitment towards relationship (Grello, Welsh, \& Harper, 2006).

\section{Conclusion}

Sexual self-control can be a suppressor of sexual desire to evade intercourse. Individual might exercise sexual selfcontrol by considering consequences of intercourse before marriage to suppress sexual desire. Individual can also internalize religion and social norms to evade intercourse before marriage. The role of sexual self-control as the buffer between sexual desire and intercourse before marriage indicated that prevention of premarital intercourse through selfcontrol is effective. Furthermore, the increased prevalence of premarital intercourse proposes new challenges for sex education to minimize its negative impact.

\section{Suggestion}

Future study can be done to clarify sexual self-control as moderator between sexual desire and premarital intercourse. This study did not examine other variables that could affect sexual self-control i.e., sexual conservatism, religiosity, and social control. Sexual education activists need to strengthen sexual self-control by emphasizing religion and social norms but should provide information to minimize the risks of premarital sexual behavior. Emerging adults who are in dating relationships are advised to exercise sexual self-control by controlling sexual desire when spending time with partners and 
also consider the consequences and risks of intercourse before marriage.

\section{References}

Aalsma, M. C., Woodrome, S. E., Downs, S. M., Hensel, D. J., Zimet, G. D., Orr, D. P., \& Fortenberry, J. D. (2013). Developmental trajectories of religiosity, sexual conservatism and sexual behavior among female adolescents. Journal of Adolescence, 36(6), 1193-1204. doi: 10.1016/j.adolescence.2013.08.005

Adam, P. C. G., Teva, I., \& de Wit, J. B. F. (2008). Balancing risk and pleasure: Sexual self-control as a moderator of the influence of sexual desires on sexual risk-taking in men who have sex with men. Sexually Transmitted Infections, 84(6), 463-467. doi: $\underline{10.1136 / \text { sti.2008.031351 }}$

Angelina, D. Y., \& Matulessy, A. (2013). Pola asuh otoriter, kontrol diri dan perilaku seks bebas remaja SMK. Persona: Jurnal Psikologi Indonesia, 2(2), 173-182. doi: 10.30996/persona.v2i2. $\underline{106}$

Arnett, J. J. (2000). Emerging adulthood: A theory of development from the late teens through the twenties. American Psychologist, 55(5), 469-480. doi: 10.1037/0003-066X.55.5.469

Arnett, J. J. (2004). Emerging adulthood: The winding road from the late teens through the twenties. New York, NY: Oxford University Press.

Arnett, J. J. (2005). The developmental context of substance use in emerging adulthood. Journal of Drug Issues, 35(2), 235-254. doi: $\underline{10.1177 / 002204260503500202}$

Aviyah, E., \& Farid, M. (2014). Religiusitas, kontrol diri dan kenakalan remaja.
Persona: Jurnal Psikologi Indonesia, 3(2), 126-129. doi: 10.30996/persona.v3i02.376

Baron, R. A., Byrne, D., \& Watson, G. (2001). Exploring social psychology. Boston: Allyn and Bacon.

Baron, R. M., \& Kenny, D. A. (1986). The moderator-mediator variable distinction in social psychological research: Conceptual, strategic, and statistical considerations. Journal of Personality and Social Psychology, 51(6), 1173-1182. doi: 10.1037/0022$\underline{3514.51 .6 .1173}$

Baumeister, R. F., Catanese, K. R., \& Vohs, K. D. (2001). Is there a gender difference in strength of sex drive? Theoretical views, conceptual distinctions, and a review of relevant evidence. Personality and Social Psychology Review, 5(3), 242-273. doi: 10.1207/S15327957PSPR0503 5

Baumeister, R. F., Vohs, K. D., \& Tice, D. M. (2007). The strength model of selfcontrol. Current Directions in Psychological Science, 16(6), 351-355. doi: 10.1111/j.1467-8721.2007.00534.x

Beck, J. G., Bozman, A. W., \& Qualtrough, T. (1991). The experience of sexual desire: Psychological correlates in a college sample. Journal of Sex Research, 28(3), 443-456. doi: $\underline{10.1080 / 00224499109551618}$

Bouffard, J. A., \& Miller, H. A. (2014). The role of sexual arousal and overperception of sexual intent within the decision to engage in sexual coercion. Journal of Interpersonal Violence, 29(11), 1967-1986. doi: $\underline{10.1177 / 0886260513515950}$

Brelsford, G. M., Luquis, R., \& MurraySwank, N. A. (2011). College students' permissive sexual attitudes: Links to religiousness and spirituality. 
International Journal for the Psychology of Religion, 21(2), 127-136. doi: $\underline{10.1080 / 10508619.2011 .557005}$

Brown, J. D., \& Cantor, J. (2000). An agenda for research on youth and the media. Journal of Adolescent Health, 27(2), 2-7. doi: 10.1016/S1054139X(00)00139-7

Bryan, A., Schindeldecker, M. S., \& Aiken, L. S. (2001). Sexual self-control and male condom-use outcome beliefs: Predicting heterosexual men's condom-use intentions and behavior. Journal of Applied Social Psychology, 31(9), 1911-1938. doi: 10.1111/j.15591816.2001.tb00210.x

Carpenter, L. M. (2002). Gender and the meaning and experience of virginity loss in the contemporary United States. Gender \& Society, 16(3), 345-365. doi: $10.1177 / 0891243202016003005$

Espinosa-Hernández, G., Vasilenko, S. A., \& Bámaca-Colbert, M. Y. (2016). Sexual behaviors in Mexico: The role of values and gender across adolescence. Journal of Research on Adolescence, 26(3), 603-609. doi: 10.1111/jora.12209

Exner, T. M., Meyer-Bahlburg, H. F. L., \& Ehrhardt, A. A. (1992). Sexual self control as a mediator of high risk sexual behavior in a New York City cohort of HIV+ and HIV- gay men. Journal of Sex Research, 29(3), 389-406. doi: $\underline{10.1080 / 00224499209551655}$

Grello, C. M., Welsh, D. P., \& Harper, M. S. (2006). No strings attached: The nature of casual sex in college students. Journal of Sex Research, 43(3), 255-267. doi: $\underline{10.1080 / 00224490609552324}$

Haidt, J. (2013). Moral psychology for the twenty-first century. Journal of Moral Education, 42(3), 281-297. doi: $\underline{10.1080 / 03057240.2013 .817327}$
Holloway, V., \& Wylie, K. (2015). Sex drive and sexual desire. Current Opinion in Psychiatry, 28(6), 424-429. doi: $\underline{10.1097 / Y C O .0000000000000199}$

Janowitz, M. (1975). Sociological theory and social control. American Journal of Sociology, 81(1), 82-108. doi: $\underline{10.1086 / 226035}$

Kavanagh, D. J., Andrade, J., \& May, J. (2005). Imaginary relish and exquisite torture: The elaborated intrusion theory of desire. Psychological Review, 112(2), 446-467. doi: 10.1037/0033295X.112.2.446

Kennett, D. J., Humphreys, T. P., \& Bramley, J. E. (2013). Sexual resourcefulness and gender roles as moderators of relationship satisfaction and consenting to unwanted sex in undergraduate women. The Canadian Journal of Human Sexuality, 22(1), 5161. doi: $\underline{10.3138 / \text { cjhs. } 933}$

Kennett, D. J., Humphreys, T. P., \& Patchell, M. (2009). The role of learned resourcefulness in helping female undergraduates deal with unwanted sexual activity. Sex Education, 9(4), 341-353.

doi: 10.1080/14681810903264702

Lefkowitz, E. S. (2005). "Things have gotten better": Developmental changes among emerging adults after the transition to university. Journal of Adolescent Research, 20(1), 40-63. doi: $\underline{10.1177 / 0743558404271236}$

Lefkowitz, E. S., Gillen, M. M., Shearer, C. L., \& Boone, T. L. (2004). Religiosity, sexual behaviors, and sexual attitudes during emerging adulthood. Journal of Sex Research, 41(2), 150-159. doi: $\underline{10.1080 / 00224490409552223}$

Lefkowitz, E. S., Vasilenko, S. A., \& Leavitt, C. E. (2016). Oral vs. vaginal sex experiences and consequences 
among first-year college students. Archives of Sexual Behavior, 45(2), 329337. doi: 10.1007/s10508-015-0654-6

Levine, S. B. (2003). The nature of sexual desire: A clinician's perspective. Archives of Sexual Behavior, 32(3), 279285. doi: 10.1023/A:1023421819465

Longest, K. C., \& Vaisey, S. (2008). Control or conviction: Religion and adolescent initiation of marijuana use. Journal of Drug Issues, 38(3), 689-715. doi: 10.1177/002204260803800303

Luquis, R. R., Brelsford, G. M., \& Pérez, M. A. (2015). Exploring Latino college students' sexual behaviors in relation to their sexual attitudes, religiousness, and spirituality. Journal of Religion and Health, 54(4), 1345-1357. doi: 10.1007/s10943-014-9929-9

Mardyantari, E., Firdauz, M., Pujiningtyas, L., Yutifa, H., Susanto, S., \& Sunarsi, S. (2018). Hubungan media pornografi dengan perilaku seksual pranikah pada remaja. Strada Jurnal Ilmiah Kesehatan, 7(1), 36-39. doi: $\underline{10.30994 / s j i k . v 7 i 1.145}$

Nurhaidah, \& Musa, M. I. (2015). Dampak pengaruh globalisasi bagi kehidupan bangsa Indonesia. Jurnal Pesona Dasar, 3(3), 1-14.

Penhollow, T., Young, M., \& Denny, G. (2005). The impact of religiosity on the sexual behaviors of college students. American Journal of Health Education, 36(2), 75-85. doi: $\underline{10.1080 / 19325037.2005 .10608163}$

Pinter, B., \& Tomori, M. (2000). Sexual behavior of secondary-school students in Slovenia. The European Journal of Contraception \& Reproductive Health Care, 5(1), 71-76. doi: $\underline{10.1080 / 13625180008500372}$

Pokhrel, P., Bennett, B. L., Regmi, S., Idrisov, B., Galimov, A., Akhmadeeva,
L., \& Sussman, S. (2018). Individualism-collectivism, social selfcontrol and adolescent substance use and risky sexual behavior. Substance Use E Misuse, 53(7), 1057-1067. doi: $\underline{10.1080 / 10826084.2017 .1392983}$

Quinn-Nilas, C., \& Kennett, D. J. (2018). Reasons why undergraduate women comply with unwanted, non-coercive sexual advances: A serial indirect effect model integrating sexual script theory and sexual self-control perspectives. The Journal of Social Psychology, 158(5), 603-615. doi: $\underline{10.1080 / 00224545.2018 .1427039}$

Quinn-Nilas, C., Kennett, D. J., \& Humphreys, T. P. (2013). Does the sexual self-control model for women apply to undergraduate men? The Canadian Journal of Human Sexuality, 22(3), 134-141. doi: 10.3138/cjhs.2169

Rahardjo, W., Citra, A. F., Saputra, M., Damariyanti, M., Ayuningsih, A. M., \& Siahay, M. M. (2017). Perilaku seks pranikah pada mahasiswa: Menilik peran harga diri, komitmen hubungan, dan sikap terhadap perilaku seks pranikah. Jurnal Psikologi, 44(2), 139. doi: 10.22146/jpsi.23659

Rahman, A. A. (2013). Psikologi sosial: Integrasi pengetahuan wahyu dan pengetahuan empirik. Jakarta: Rajawali Pers.

Rany, N. (2012). Perilaku seks pranikah pada mahasiswa STIKes Hang Tuah Pekanbaru. Jurnal Kesehatan Komunitas, 2(1), $35 . \quad$ doi: $\underline{10.25311 / \mathrm{jkk} . V o l 2 . I s s 1.40}$

Reiss, I. L. (1964). The scaling of premarital sexual permissiveness. Journal of Marriage and the Family, 26(2), 188. doi: $\underline{10.2307 / 349726}$ 
Rostosky, S. S., Regnerus, M. D., \& Wright, M. L. C. (2003). Coital debut: The role of religiosity and sex attitudes in the add health survey. Journal of Sex Research, 40(4), 358-367. doi: $\underline{10.1080 / 00224490209552202}$

Sarwono, S. W. (2013). Psikologi remaja edisi revisi. Jakarta: Rajawali Pers.

Savioja, H., Helminen, M., Fröjd, S., Marttunen, M., \& Kaltiala-Heino, R. (2018). Adolescent sexual behaviorfamily characteristics, parental involvement, and associated mental disorders. International Journal of Sexual Health, 1-14. doi: $\underline{10.1080 / 19317611.2018 .1494077}$

Smiler, A. P. (2008). "I wanted to get to know her better": Adolescent boys' dating motives, masculinity ideology, and sexual behavior. Journal of Adolescence, 31(1), 17-32. doi: 10.1016/j.adolescence.2007.03.006

Smith, L. H., Guthrie, B. J., \& Oakley, D. J. (2005). Studying adolescent male sexuality: Where are we? Journal of Youth and Adolescence, 34(4), 361-377. doi: 10.1007/s10964-005-5762-5

Spector, I. P., Carey, M. P., \& Steinberg, L. (1996). The sexual desire inventory: Development, factor structure, and evidence of reliability. Journal of Sex $\mathcal{E}$ Marital Therapy, 22(3), 175-190. doi: $\underline{10.1080 / 00926239608414655}$

Suwarsi, S. (2016). Analisis faktor penyebab perilaku seksual pranikah pada remaja di desa Wedomartani Sleman Yogyakarta. Jurnal Ners dan Kebidanan Indonesia, 4(1), 39-43. doi: 10.21927/jnki.2016.4(1).39-43

Toates, F. (2009). An integrative theoretical framework for understanding sexual motivation, arousal, and behavior. Journal of Sex Research, 46(2-3), 168193. doi: $10.1080 / 00224490902747768$
Ugoji, F. N. (2014). Determinants of risky sexual behaviours among secondary school students in Delta State Nigeria. International Journal of Adolescence and Youth, 19(3), 408-418. doi: 10.1080/02673843.2012.751040

VandenBos, G. R. (2006). APA dictionary of psychology. Washington DC: American Psychological Association.

Vasilenko, S. A., Duntzee, C. I., Zheng, Y., \& Lefkowitz, E. S. (2013). Testing two process models of religiosity and sexual behavior. Journal of Adolescence, 36(4), 667-673. doi: 10.1016/j.adolescence.2013.04.002

Vasilenko, S. A., \& Espinosa-Hernández, G. (2019). Multidimensional profiles of religiosity among adolescents: Associations with sexual behaviors and romantic relationships. Journal of Research on Adolescence, 29(2), 414-428. doi: 10.1111/jora.12444

Vasilenko, S. A., Espinosa-Hernández, G., \& Halgunseth, L. C. (2016). Positive and negative perceived consequences of first intercourse among middle and high school students in Puebla, Mexico. Culture, Health $\mathcal{E}$ Sexuality, 18(5), 582-596. doi: $\underline{10.1080 / 13691058.2015 .1101164}$

Vasilenko, S. A., Linden-Carmichael, A., Lanza, S. T., \& Patrick, M. E. (2018). Sexual behavior and heavy episodic drinking across the transition to adulthood: Differences by college attendance. Journal of Research on Adolescence, 28(2), 473-487. doi: $\underline{10.1111 / j o r a .12348}$

Vasilenko, S. A., Maas, M. K., \& Lefkowitz, E. S. (2015). "It felt good but weird at the same time": Emerging adults' first experiences of six different sexual behaviors. Journal of Adolescent 
Research, 30(5), 586-606. doi: $\underline{10.1177 / 0743558414561298}$

Victor, E. C., Miles, A., \& Vaisey, S. (2015). The role of moral worldviews in predicting sexual behavior from adolescence to emerging adulthood. Journal of Adolescent Research, 30(6), 779-799.

doi: $\underline{10.1177 / 0743558414561294}$

Willoughby, B. J., \& Carroll, J. S. (2010). Sexual experience and couple formation attitudes among emerging adults. Journal of Adult Development,
17(1), 1-11. doi: 10.1007/s10804-009$\underline{9073-\mathrm{Z}}$

Yan, H., Li, L., Bi, Y., Xu, X., Li, S., \& Maddock, J. E. (2010). Family and peer influences on sexual behavior among female college students in Wuhan, China. Women \& Health, 50(8), 767782. doi: $10.1080 / 03630242.2010 .530926$

Yoon, G. J. (2004). Predicting Korean adolescents' sexual behavior. Marriage $\mathcal{E}$ Family Review, 36(1-2), 147-173. doi: 10.1300/J002v36n01 07 